\title{
Characterization of enteroaggregative Escherichia coli among diarrheal children in Western Brazilian Amazon
}

\author{
Roger Lafontaine Mesquita TABORDA ${ }^{1}$, Luiz Antônio da SILVA ${ }^{1}$ Patricia Puccinelli ORLANDI ${ }^{2}$ \\ Flávia Serrano BATISTA ${ }^{1}$, Renata Santos RODRIGUES ${ }^{1}$ and Najla Benevides MATOS1,3
}

Received 17/7/2018

\begin{abstract}
Background - Enteroaggregative Escherichia coli (EAEC) is one of the main acute and chronic diarrhea causes both in children and adults, mainly in developing countries. Objective - The aim of the present study is to characterize EAEC strains isolated from faecal samples and to identify genes potentially contributing to virulence, biofilm production and antimicrobial resistance in children admitted to a pediatric hospital in Porto Velho, Rondônia State. Methods - The total of 1,625 E. coli specimens were isolated from 591 children in the age group 6 years or younger who were hospitalized in Cosme and Damião Children Hospital in Porto Velho, between February 2010 and February 2012, with acute gastroenteritis. Colonies suggestive of $E$. coli were subjected to polymerase chain reaction testing in order to identify the virulence factors. The in vitro adhesion assays using HEp-2 adherence were tests. Biofilm detection through spectrophotometry and antimicrobial susceptibility tests were conducted in the disk diffusion method. Results - The mentioned study examined 591 stool samples from children with diarrhea. Diarrheogenic E. coli was found in 27.4\% (162/591) of the children. EAEC was the diarreagenic E. coli most frequently associated with diarrhea $52.4 \%(85 / 162)$, which was followed by enteropathogenic E. coli $43.8 \%$ (71/162), enterotoxigenic $E$. coli $2.4 \%(4 / 162)$, and enterohemorrhagic $E$. coli $1.2 \%(2 / 162)$. The agg $R$ gene was detected in $63.5 \%(54 / 85)$ of EAEC isolates; moreover, statistically significant correlation was observed among typical EAEC (aggR) and aat $A(P<0.0001)$, irp2 $(P=0.0357)$ and $\operatorname{shf}(P=0.0328)$. It was recorded that $69 \%(59 / 85)$ of the 85 analyzed EAEC strains were biofilm producers; $73 \%(43 / 59)$ of the biofilm producers carried the $\operatorname{agg} R$ gene versus $42.3 \%(11 / 26)$ of non-producers $(P=0.0135)$. In addition, there was association between the aat $A$ gene and biofilm production; $61 \%(36 / 59)$ of the samples presented producer strains, versus $19.2 \%(5 / 26)$ of non-producers $(P<0.0004)$. Antibiotic sensitivity test evidenced that most EAEC were ampicillin 70.6\% (60/85), sulfamethoxazole 60\% (51/85), tetracycline 44.7\% (38/85) and cefotaxime 22.4\% (19/85) resistant. Conclusion - As far as it is known, the present study is pioneer in Northern Brazil to investigate EAEC virulence factors and to show the antimicrobial susceptibility of EAEC strains isolated from children with diarrhea.
\end{abstract}

HEADINGS - Escherichia coli, classification. Infantile diarrhea. Child. Virulence, genetics.

\section{INTRODUCTION}

According to the World Health Organization (WHO), diarrhea is the second leading morbidity and mortality cause among children in the age group 5 years or younger. Diarrhea resulted in 530,000 deaths in 2015, or in approximately 1,400 deaths per day, worldwide $^{(1)}$. The main diarrheal-syndrome causes in children include inappropriate hygiene, insufficient water and food sanitation, besides lack of adequate health infrastructure ${ }^{(2)}$. Several viral, bacterial and parasitic agents are associated with diarrhea, among them bacteria belonging to species Escherichia coli (which is a natural species composing the intestinal flora). This species is strongly associated with diarrhea cases in children due to the acquisition of specific virulence factors contributing to its pathogenicity, the so-called diarreagenic E. coli $(\mathrm{DEC})^{(3)}$.
Diarreagenic $E$. coli is divided in six pathotypes depending on the pathogenicity mechanism, namely: enteropathogenic $E$. coli (EPEC), enterohemorrhagic E. coli (EHEC), enteroinvasive $E$. coli, enteroaggrevative $E$. coli (EAEC), enterotoxigenic $E$. coli (ETEC) and diffusely adherent E. coli ${ }^{(4)}$. The EAEC is associated with chronic and persistent diarrhea cases in developing countries, besides being one of the most relevant opportunistic pathogens affecting HIV patients. However, despite the several advances concerning the understanding about this bacterium species, its infection mechanism is not entirely understood because the heterogeneity of the pathogen impairs a proper diagnosis, as well as the understanding about its pathogenicity ${ }^{(5)}$.

Previous studies have described the three-stage model applied to EAEC pathogenesis: 1- initial adherence to mucosal surface, 2- biofilm formation, and 3-inflammatory response induction and

Declared conflict of interest of all authors: none

Disclosure of funding: no funding received

${ }^{1}$ Centro de Pesquisa em Medicina Tropical, Porto Velho, RO, Brasil. ${ }^{2}$ Instituto Leônidas \& Maria Deane, Fundação Oswaldo Cruz, Manaus, AM, Brasil. ${ }^{3}$ Fundação Oswaldo Cruz, FIOCRUZ Porto Velho, RO, Brasil.

Corresponding author: Najla Benevides Matos. Orcid: 0000-0002-7271-5764. E-mail: najlamatos@fiocruz.br 
toxin release. Several virulence factors affect the infection process; however, they can be used as pathogenesis identification markers ${ }^{(6)}$.

The EAEC strains are defined in HEp-2 cells through their aggregative adherence (AA) or "stacked brick" phenotype, which is the gold standard method to identify such pathogen. However, the adherence test is not able to distinguish pathogenic from nonpathogenic EAEC strains. In addition, molecular biology assays based on virulence factor detection have been widely used to identify and characterize DEC isolates $^{(7)}$. The use of molecular techniques, and of epidemiological studies on this isolates, to investigate virulence markers in EAEC is important. Studies have been demonstrating that EAEC strains are heterogeneous and complex groups associated with many virulence factors. Different gene targets have been used to detect EAEC by using polymerase chain reaction (PCR). The knowledge about this genes and their function has been making the development of diagnostic methods and the understanding about the pathogenicity of EAEC possible ${ }^{(8)}$.

Some studies adopted the PCR technique to conduct EAEC molecular identification of DEC categories or to assess the presence of specific virulence factors associated with genes such as aggregative adherence fimbriae (AAFs), transcriptional activator $(\operatorname{agg} R)^{(9)}$, plasmid-encoded toxin $(\text { pet })^{(10)}$, Shigella enterotoxin 1 $(\text { ShET1) })^{(11)}$, EAEC heat-stable enterotoxin (EAST1) $)^{(12)}$, mucinase activity $(\mathrm{Pic})^{(11)}$, secreted proteins (aap) ${ }^{(13)}$, dispersin transporter (aatA) $)^{(14)}$, and yersiniabactin system (irp2) ${ }^{(15)}$ associated with genes in EAEC. The $\operatorname{agg} R$ gene is important for the pathogenesis and adherence properties of EAEC; moreover, the presence or absence of $\operatorname{agg} R$ is used to classify EAEC as typical or atypical, respectively.

The biofilm formation has been linked to several human diseases. Biofilms are highly organized communities of microorganisms structured within an array of exopolysaccharides (EPS) ${ }^{(16)}$. The bacterial arranged in biofilms tend to be more resistant to antimicrobial therapy, and the ability to biofilm formation in combination with the heterogeneity of virulence genes have been evidenced in EAEC strains ${ }^{(17)}$.

In addition to mechanisms directly related to virulence, the antimicrobial resistance has been identified through clinical and non-clinical EAEC sources. The antimicrobial resistance has been seen as one of the most important factors to help assessing the impact this pathogen has on public health, and EAEC associated with multidrug resistant (MDR) was reported from different parts of the world ${ }^{(19)}$. MDR is defined as acquired non-susceptibility to at least one agent in three or more antimicrobial categories ${ }^{(19)}$.

Since EAEC is one of the main agents causing diarrhea, mainly in developing countries, it is worth conducting characterization and epidemiological surveillance studies, mainly in Northern Brazil, where public and environmental health is directly associated with poverty. Porto Velho is the capital of Rondônia State (Western Brazilian Amazon); the city is among the worst capitals when it comes to basic sanitation. Such poor sanitation condition has strong impact on local health indicators, which depict the epidemiological scenario in the region, as well as the high incidence of diarrheal diseases and infant mortality rates. Given the need of setting the profile of aetiological agents causing acute gastroenteritis, the aim of the present study was to characterize EAEC strains isolated from faecal samples and to identify genes potentially contributing to virulence, biofilm production and antimicrobial resistance in children admitted to a pediatric hospital in Porto Velho, Rondônia.

\section{METHODS}

\section{Study site and patients}

The total of 1,625 E. coli specimens were isolated from 591 children in the age group 6 years or younger who were hospitalized in Cosme and Damião Children Hospital in Porto Velho, between February 2010 and February 2012, with acute gastroenteritis. Cases were defined as acute gastroenteritis when patients presented liquid or semi-liquid stools, and three or more evacuations within 24-h periods. Sample collection was carried out three times a week, for two consecutive years. One fecal sample was collected from each child participating in the experiment. A sterile universal collector was used during the collection procedure. The samples were registered, labeled and stored at $-80^{\circ} \mathrm{C}$. The experiment was approved by the Ethical Committee of Rondônia Tropical Medicine Research Centre (protocol N. 0113/2010).

\section{Bacteriology}

E. coli strains were selected from MacConkey, SalmonellaShigella and xylose lysine deoxycholate selective agar provided by HiMedia U.S.A selective agar. All colonies were processed through routine microbiological and biochemical tests purchased at bioMérieux France (API20E system). Five colonies suggestive of $E$. coli were subjected to PCR testing in order to identify the virulence factors.

\section{HEp-2 adherence test}

All E. coli isolates were subjected to HEp-2 adherence tests ${ }^{(20)}$. The EAEC 042 was used as aggregative adherence positive control.

\section{Analysis of $E$. coli virulence factors through multiplex polymerase chain reaction (PCR)}

The EAEC virulence factors $\operatorname{agg} R$, ast $A$, and pic were identified through PCR by using specific primers as previously described by Müller et al. ${ }^{(18)}$. The aat A, shet $1 A$, shf, irp2, and pet virulence factors were identified according to the method described by Mohamed et al. ${ }^{(17)}$.The EAEC 042 was used as positive control. Non-pathogenic E. coli strain HB101 was used as negative control, as well as to monitor PCR contamination.

\section{Biofilm detection through spectrophotometry}

The 96-well polystyrene microtiter plates were used to detect biofilms on polystyrene, according to previously described procedures ${ }^{(21)}$. The following strains were used to assure the quality of the biofilm assay: Pseudomonas aeruginosa PAOI, EAEC 042 - which is a strong biofilm producer, and the non-pathogenic $E$. coli strain HB101 (negative control).

\section{Antimicrobial sensitivity test}

Antimicrobial susceptibility tests were conducted in MuellerHinton agar (HiMedia U.S.A) through the disk diffusion method, according to Clinical and Laboratory Standards Institute guidelines $^{(22)}$. Gentamicin (GEN $10 \mu \mathrm{g}$ ), imipenem (IMP $10 \mu \mathrm{g}$ ), piperacillin/tazobactam (TZP $10 \mu \mathrm{g}$ ), tetracycline (TET $30 \mu \mathrm{g}$ ), trimethoprim/sulfamethoxazole (SXT $25 \mu \mathrm{g}$ ), amoxicillin/clavulanic acid (AMC $30 \mu \mathrm{g}$ ), amikacin (AMI $30 \mu \mathrm{g}$ ), ampicillin (AMP $10 \mu \mathrm{g}$ ), cefotaxime (CTX $30 \mu \mathrm{g}$ ), and ceftazidime (CFZ $30 \mu \mathrm{g}$ ) antibiotic disks (Sensifar-cefar ${ }^{\circledR}$, Brazil) were used. The E. coli strain ATCC 25922 was used for quality control in all tests. 


\section{Statistical analysis}

Data were analyzed through Fisher's exact test conducted in GraphPad Prism 5.0. Results were significant at $P$-values $<0.05$.

\section{RESULTS}

\section{Pathogens associated with diarrhea}

Pathogenic agent isolates analyzed in the study were taken from a study conducted from February 2010 to February 2012 in Porto Velho, Rondonia, Brazil. The mentioned study examined 591 stool samples from children with diarrhea. Diarrheogenic $E$. coli was found in $27.4 \%(162 / 591)$ of the children. EAEC was the DEC most frequently associated with diarrhea $-52.4 \%(85 / 162)$, which was followed by EPEC 43.8\% (71/162), ETEC 2.4\% (4/162), and EHEC 1.2\% (2/162). Among other enteropathogenic bacteria, Salmonella sp was found in 7.1\% (42/591) cases and Shigella species were recorded in $2.1 \%(13 / 591)$ of the cases.

The mean age of the patients was 17.2 months; nonetheless, this pathotype incidence was higher in children under 2 years old, although there was not statistically significant difference.

The total of 85 EAEC isolates (all of them presenting aggregative adherence pattern) from 51 patients were identified through cell assays in order to characterize cellular adhesion. All EAEC strains were subjected to the PCR technique in order to find the virulence factors. Infection caused by EAEC was detected in both male $60.8 \%(31 / 51)$ and female $39.2 \%(20 / 51)$ patients. Typical EAEC (aggR-positive) was found in 63,5\% (54/85) and atypical EAEC (agg $R$-negative) in $36.5 \%(31 / 85)$ of the strains (TABLE1).

TABLE 1. Distribution of epidemiological factors among children infected by EAEC.

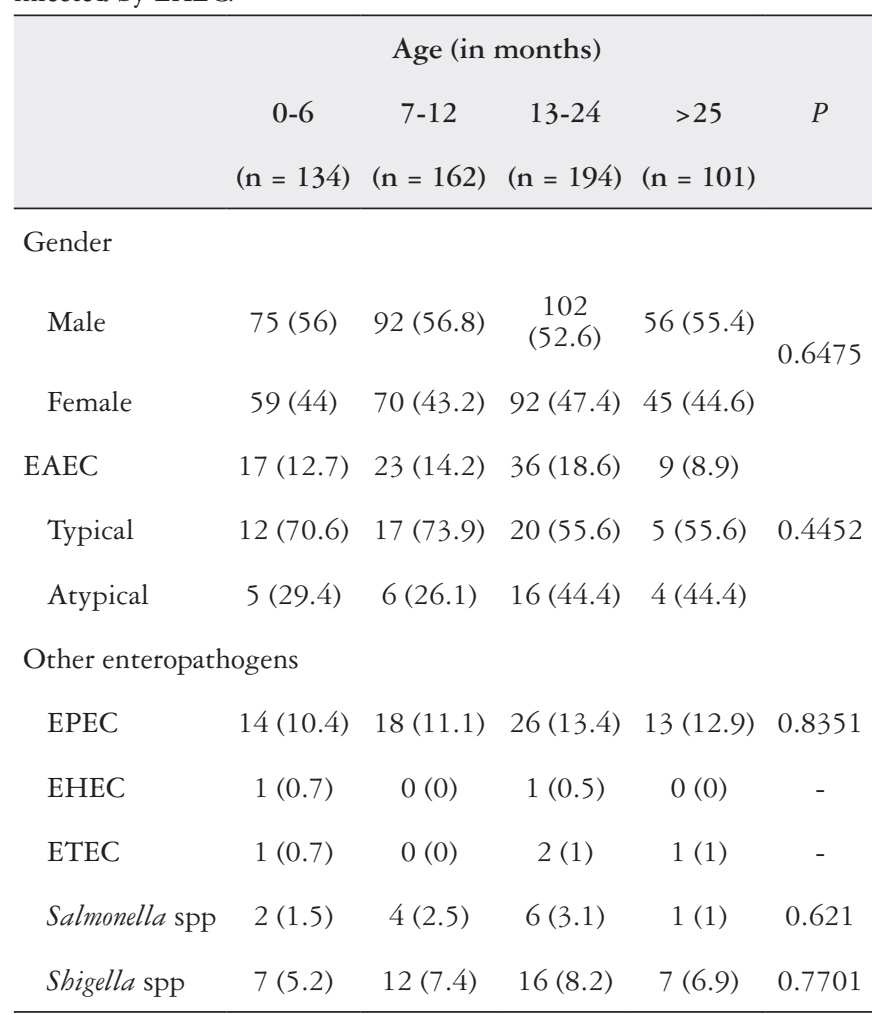

EAEC: enteroaggrevative E. coli; EPEC: enteropathogenic E. coli; EHEC: enterohemorrhagic E. coli; ETEC: enterotoxigenic E. coli.
All children participating in the study presented typical enteropathogen infection symptoms including diarrhea, vomiting and fever. Bloody diarrhea was recorded in $23.5 \%(12 / 51)$ of the cases and EAEC was the only pathogen detected in $58.3 \%(7 / 12)$ of these cases.

\section{Prevalence of virulence genes}

One or more virulence marker genes were detected in all EAEC isolates. The irp 2 gene was the most commonly identified one, since it was recorded in $75.3 \%(64 / 85)$ of the isolates; it was followed by ast $A, \operatorname{agg} R$, and aat $A$, which were found in $64.7 \%,(55 / 85), 63.5 \%$ $(54 / 85)$, and $48.2 \%(41 / 85)$ of the isolates, respectively. In addition, many other genes were involved in EAEC pathogenesis, including set $1 A$, afal, shf, pic, and pet, these genes were more often found in typical EAEC strains than in atypical EAEC strains. There was statistically significant correlation between typical EAEC and the presence of aat $A(P<0.0001)$, irp2 $(P=0.0357)$ or $\operatorname{shf}(P=0.0328)$ genes (TABLE 2).

TABLE 2. Incidence of virulence genes in typical and atypical enteroaggrevative $E$. coli strains.

\begin{tabular}{|c|c|c|c|c|}
\hline $\begin{array}{l}\text { Virulence } \\
\text { factors }\end{array}$ & $\begin{array}{l}\text { Typical } \\
\text { n (\%) }\end{array}$ & $\begin{array}{l}\text { Atypical } \\
\text { n (\%) }\end{array}$ & $P$-value & OR (IC 95\%) \\
\hline $\operatorname{set} 1 A$ & $19(35.2)$ & $14(45.2)$ & 0.4883 & $0.66(0.24-1.8)$ \\
\hline ast $A$ & $37(68.5)$ & $18(58.1)$ & 0.3548 & $1.56(0.57-4.31)$ \\
\hline afal & $19(35.2)$ & $15(48.4)$ & 0.2574 & $0.58(0.21-1.57)$ \\
\hline aat $A$ & $36(66.7)$ & $5(16.1)$ & $<0.0001$ & $10.08(3.13-39.43)$ \\
\hline Pet & $7(13)$ & $1(3.2)$ & 0.2483 & $4.41(0.52-207.77)$ \\
\hline $\operatorname{irp2}$ & $45(83.3)$ & $19(61.3)$ & 0.0357 & $3.11(1.01-9.94)$ \\
\hline $\operatorname{Shf}$ & $24(44.4)$ & $6(19.4)$ & 0.0328 & $3.29(1.08-11.42)$ \\
\hline Pic & $15(27.8)$ & $7(22.6)$ & 0.7975 & $1.31(0.43-4.39)$ \\
\hline biofilm & $43(79.6)$ & $16(51.6)$ & 0.0134 & $3,603(1.253-10.789)$ \\
\hline
\end{tabular}

\section{Association with biofilm production}

Of the 85 analyzed EAEC strains, 69.4\% (59/85) were biofilm producers; therefore, there was statistically significant relation between biofilm production and the presence of $a g g R$ gene (TABLE 2). It is worth highlighting that $73 \%$ (43/59) of the biofilm producers had the $\operatorname{agg} R$, whereas this gene frequency in non-producer strains was $42.3 \%(11 / 26 ; P=0.0135[\mathrm{OR}=3.665 ; \mathrm{IC} 95 \%=1.393$ to 9.639$])$. Similarly, there was association between the presence of aat $A$ gene and biofilm producers (61\% [36/59]), versus $19.2 \%(5 / 26)$ association in non-producers; $P=0.0004$ [OR=6.574; IC95\% 2.173 to 19.89$]$. No correlation was observed between biofilm production and the presence of other virulence genes such as $\operatorname{set} 1 A$, afal, irp2, pic, ast A, pet, and $\operatorname{shf}$ (FIGURE 1). 


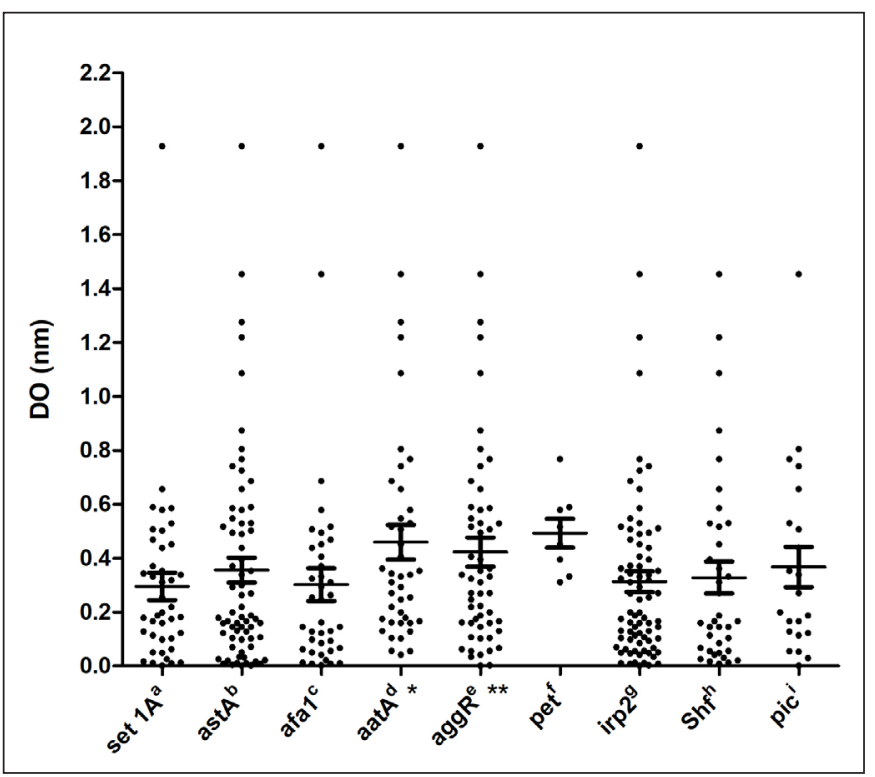

FIGURE 1. Biofilm formation and presence of virulence genes in EAEC isolates among diarrheal children. ${ }^{\text {a }}$ shigella enterotoxin 1 ; ${ }^{\text {b }}$ enteroaggregative heat-stable enterotoxin $1 ;{ }^{\mathrm{c}}$ aggregative adherence; factor; ${ }^{\mathrm{d}}$ dispersin transporter; ${ }^{\mathrm{e}}$ transcriptional activator; ${ }^{\mathrm{f}}$ plasmid encoded toxins; ${ }^{g}$ yersiniabactin biosynthesis; ${ }^{\mathrm{h}}$ cryptic open reading frame; ${ }^{\mathrm{i}}$ mucinase activity genes. $P$ values represent correlation between biofilm production and virulence genes in EAEC: ${ }^{*} P=0.0004 ; * * P=0.0135$ (Fisher's exact test).

\section{Antibiotic sensitivity in EAEC isolates}

All 85 EAEC isolates were tested against 10 different antibiotics; the susceptibility profiles are shown in TABLE 3. At least one strain resistant to each of the tested antibiotics was identified. Results evidenced that most EAEC isolates were resistant to AMP $70.6 \%$ (60/85), SXT 60\% (51/85), TET 44.7\% (38/85), and CTX $22.3 \%(19 / 85)$. Multidrug resistance (MDR) was detected in $36.5 \%$ $(31 / 85)$ of the tested strains. The MDR strains were resistant to antibiotics belonging to the most common chemotherapy classes, including AMP 96.8\% (30/31), SXT 96.8\% (30/31), TET 61.3\% (19/31), CTX 54.8\% (17/31).

TABLE 3. Antimicrobial profiles of EAEC: enteroaggrevative E. coli isolates.

\begin{tabular}{lcc}
\hline Antibiotic & Sensitive $\mathbf{n}(\%)$ & Resistant $\mathbf{n}(\%)$ \\
\hline Amoxicilin/clavulanic acid (AMC) & $61(71.8)$ & $24(28.2)$ \\
Amikacin (AMI) & $83(97.6)$ & $2(2.4)$ \\
Ampicillin (AMP) & $25(29.4)$ & $60(70.6)$ \\
Cefotaxime (CTX) & $66(77.6)$ & $19(22.3)$ \\
Ceftazime (CRX) & $70(82.4)$ & $15(17.6)$ \\
Gentamicin (GEN) & $72(84.7)$ & $13(15.3)$ \\
Imipenem (IPM) & $80(94.1)$ & $5(5.9)$ \\
Piperacillin/tazobactam (PPT) & $75(88.2)$ & $10(11.8)$ \\
Tetracycline (TET) & $47(55.3)$ & $38(44.7)$ \\
Sulfamethoxazole (STX) & $34(40)$ & $51(60)$ \\
\hline
\end{tabular}

\section{DISCUSSION}

Studies about the interaction and importance of different pathogenic E. coli strains associated with acute diarrhea in Brazil have highlighted EPEC as the major etiologic agent of infant diarrhea $^{(23,24)}$. However, studies have been reporting EAEC as an emerging enteric pathogen that causes persistent diarrhea and malnutrition in children living in developed countries ${ }^{(25)}$.

With regard to the current study, 8.6\% (51/591) of childhood gastrointestinal singular infection or co-infection by other enteropathogens could be attributed to EAEC. Studies conducted abroad reported EAEC infection prevalence from $2 \%$ to $24 \%{ }^{(26,27)}$. Previous studies carried out in Brazil showed that $0.5 \%$ to $41 \%$ of acute gastroenteritis cases requiring hospitalization were caused by this pathotype $^{(28-30)}$. The high incidence of diarrhea cases in developing countries can be attributed to standard fecal-oral contamination routes resulting from deficient sanitary infrastructure, low education level, nutritional deficiency and inappropriate personal and foodrelated hygiene practices. Such incidence results in high economic burden for national public health systems ${ }^{(31,32)}$. It is worth emphasizing that patients in the current study presented critical social patterns related to low per capita income and untreated water intake.

Diarrheagenic $E$. coli infections in the current study most affected children in the age group 2 years or younger. Besides diarrhea, the major clinical symptoms associated with DEC among the assessed children were vomiting and fever. This outcome is consistent with reports from India( ${ }^{(33)}$, Tanzania ${ }^{(34)}, \operatorname{Libya}^{(35)}$, Cambodia ${ }^{(36)}$, Panama $^{(37)}$, and Israel(38).

There are just few reports about bloody diarrhea cases associated with EAEC and they rarely concern children ${ }^{(5,33)}$. With regard to the current study, bloody diarrhea was observed in $23.5 \%(12 / 51)$ of the assessed cases and EAEC was identified as the only pathogen in $58.3 \%(7 / 12)$ of them; however, other studies have reported conflicting results. A study conducted in Nigeria did not identify bloody stool as symptom of childhood EAEC infection ${ }^{(26)}$. The prevalent virulence genes in the herein analyzed isolates were irp2, in $75.3 \%(64 / 85)$ of the cases; ast $A$, in $64.7 \%(55 / 85)$; and $\operatorname{agg} R$, in $63.5 \%$ (54/85). Previous studies have reported irp 2 genes in EAEC samples but it was rarely found in EPEC, enteroinvasive $E$. coli and ETEC, besides being absent in EHEC, Shigella and Salmonella enterica $^{(17,39)}$. The irp2 gene is part of the High-pathogenicity island found in the chromosome of Yersinia species ( Y. pestis, Y. pseudotuberculosis sorotype $\mathrm{O} 1$ and Y.enterocolitica biotype 1B) involved in iron uptake, which is mediated by the siderophore yersiniabactin and found in EAEC 042.

Elias et al., 2002, used the EAEC probe and found that irp2 was the second most prevalent marker $(91.4 \%)$ among the 70 EAEC probe + strains ${ }^{(40)}$. There was statistically significant association between the typical EAEC aat $A(P<0.0001)$ and irp2 $(P=0.0357)$ genes. Patzi-Vargas conducted a study about DEC carrying supplementary virulence genes; he showed that the aat $A$ genes are significantly more common in EAEC isolates than in non-DEC strains $^{(25)}$. Tokuda et $\mathrm{al}^{(41)}$ showed that aat $A$ and irp 2 genes are more prevalent in typical EAEC isolates than in atypical ones. Results in the present study evidenced a whole variety of virulence genes combinations in typical EAECs, fact that was not so common in atypical EAECs.

Some researchers have assumed that several virulence gene combinations can be directly associated with diarrhea or with strain virulence ${ }^{(35,42)}$. 
Pathogenic implications of $\operatorname{agg} R$ gene have been assessed in a number of studies worldwide ${ }^{(17,41)}$. Interestingly, current results showed that children over one month old presented greater risk of being infected by typical than by atypical EAEC $(P=0.0155)$. These findings suggest that children have greater probability of being exposed to the most virulent strains as they age.

Andrade and collaborators showed that EAEC strains found in small intestine and colon mucosa produce large amounts of biofilm and cause changes in the epithelia, fact that possibly explains the long duration of diarrheal episodes ${ }^{(43)}$. Biofilm production, adhesiveness and other EAEC virulence factors are directly associated with certain genes, including the regulatory gene $\operatorname{agg} R$. The $\operatorname{agg} R$ is one of the most studied genes since it controls the expression of other genes related to EAEC pathogenesis. The presence of $\operatorname{agg} R$ in the present study was indeed statistically correlated with biofilm production $(P=0.0135)$; this finding corroborates findings reported in studies conducted in Mexico and Mongolia, which have also indicated that the presence of $a g g R$ gene is associated with biofilm formation $^{(44,45)}$. Although it was possible recording significant association between the presence of aat $A$ gene and biofilm production $(P=0.0004)$, the $s h f$ gene and biofilm production were not correlated to each other. This results were different from those evidenced in a previous study that correlated $s h f$ with biofilm formation, even when it was associated with $\operatorname{agg} R^{(46)}$.

Antimicrobial resistance, in EAEC populations, mainly MDR, has been reported in several studies ${ }^{(47,48)}$. Results in the present study evidenced greater EAEC resistance to AMP, SXT, TET and CTX than to other antibiotics. The resistance to these antibiotics was expected since they are the low-cost chemotherapeutic drugs of choice in many studies ${ }^{(49)}$. Antibiotics, mainly $\beta$-lactams, are often used to treat DEC infections, mainly in persistent diarrhea cases when the infectious agent is not identified, although these infections are self-limiting and only require oral-rehydration therapy. Most of the herein tested EAECs showed MDR phenotype, and this result is consistent with other studies. The most common MDR phenotypes recorded in the current study included resistance to $\beta$-lactams, TET, aminoglycosides, SXT, and GEN. There was no association between antimicrobial resistance and biofilm production, although this correlation was previously described by other researchers ${ }^{(50)}$.

As far as it is known, the present study is pioneer in showing the pathogenic potential and heterogeneity of virulence EAEC genes and co-infections caused by other enteric pathogens in children with gastroenteritis living in Rondônia. Data presented in the current study may contribute to the better understanding about the role played by EAEC in children with diarrheal illnesses living in Porto Velho. The results may help developing strategic plans to control antimicrobial resistance in these poor regions.

\section{ACKNOWLEDGEMENTS}

The authors thank all the children and their parents who enrolled in this study. The Rosimeire Cristina Dalla Marta, and Nucia Cristiane da Silva Lima for helping in the laboratory analysis, and Paulo Afonso Nogueira for statistical analyses. We thank the Cosme and Damião Children Hospital for pacient recruitment. This research was supported by grants from Instituto de Pesquisa em Patologias Tropicais (IPEPATRO), Conselho Nacional de Desenvolvimento Científico e Tecnológico (CNPq), Ministério da Saúde - Programa Pesquisa para o SUS (PPSUS), and Fundação de Amparo à Pesquisa do Estado de Rondônia (FAPERO).

\section{Authors' contribution}

Taborda RLM, Silva LA, and Rodrigues RS: collected data for the study, and carrying out the cell adhesion assays and biofilm formation. Batista FS, and Orlandi PP: reviewers of the current article. Matos NB: design and execution of the project.

Taborda RLM, Silva LA, Orlandi PP, Batista FS, Rodrigues RS, Matos NB. Caracterização de Escherichia coli enteroagregativa entre crianças com diarreia na Amazônia ocidental brasileira. Arq Gastroenterol. 2018;55(4):390-6.

RESUMO - Contexto - A Escherichia coli enteroagregativa (EAEC) é um dos principais agentes causadores de diarreia aguda e crônica em crianças e adultos, principalmente em países em desenvolvimento. Objetivo - Caracterizar cepas de EAEC isoladas de amostras fecais e identificar genes que potencialmente contribuem para a virulência, produção de biofilme e resistência antimicrobiana em crianças internadas em um hospital pediátrico em Porto Velho, Rondônia. Métodos - Um total de 1.625 cepas de $E$. coli foram isolados de 591 crianças com gastroenterite aguda na faixa etária de 6 anos que foram internadas no Hospital Infantil Cosme e Damião na cidade de Porto Velho, entre fevereiro de 2010 e fevereiro de 2012 . Colônias sugestivas de $E$. coli foram submetidas a reação em cadeia da polimerase para identificação de fatores de virulência. $\mathrm{O}$ ensaio de adesão in vitro foi desenvolvido com célula HEp-2. A detecção de biofilme foi realizada através do teste de espectrofotometria e os testes de susceptibilidade aos antimicrobiana foram realizados através do método de difusão em disco. Resultados - A E. coli diarreiogênica foi encontrada em 27,4\% (162/591) das crianças e a EAEC foi a $E$. coli diarreiogênica mais frequentemente associada à diarreia com 52,4\% (85/162), seguida pela $E$. coli enteropatogênica $43,8 \%$ (71/162), E. coli enterotoxigênica 2,4\% (4/162) e E. coli enterohemorrágica 1,2\% (2/162). O gene agg $R$ foi detectado em 63,5\% (54/85) dos isolados de EAEC com correlação estatisticamente significante entre esse gene com os genes aatA $(P<0,0001)$, irp2 $(P=0,0357)$ e $\operatorname{shf}(P=0,0328)$. Neste estudo 69\% (59/85) das cepas de EAEC eram produtoras de biofilme, destas 73\% (43/59) possuíam o gene agg $R$, ao passo que entre as não produtoras $42,3 \%(11 / 26)$ possuíam o gene ( $P=0,0135)$. Essa associação também foi observada com o gene aatA, presente em $61 \%$ (36/59) das cepas produtoras e em 19,2\% (5/26) das não produtoras $(P<0,0004)$. O teste de sensibilidade aos antibimicrobianos evidenciou que a maioria das EAEC eram resistentes a ampicilina 70,6\% (60/85), ao sulfametoxazol 60\% (51/85), a tetraciclina 44,7\% (38/85) e a cefotaxima 22,4\% (19/85). Conclusão - Este é o primeiro estudo no Norte do Brasil sobre a investigação dos fatores de virulência de EAEC mostrando a susceptibilidade antimicrobiana de cepas de EAEC isoladas de crianças com diarreia.

DESCRITORES - Escherichia coli, classificação. Diarreia infantil. Criança. Virulência, genética. 


\section{REFERENCES}

1. WHO. UNICEF. Diarrhoea remains a leading killer of young children, despite the availability of a simple treatment solution. Monitoring the Situation of Children and Women. 2017.

2. Nweze EI. Aetiology of diarrhoea and virulence properties of diarrhoeagenic Escherichia coli among patients and healthy subjects in Southeast Nigeria. J Heal Popul Nutr. 2010;28:245-52.

3. Beau De Rochars VEM, Alam MT, Telisma T, Masse R, Chavannes S, Anilis MG, et al. Spectrum of Outpatient Illness in a School-Based Cohort in Haiti, with a Focus on Diarrheal Pathogens. Am J Trop Med Hyg. 2015;92:752-7.

4. Nataro JP, Kaper JB. Diarrheagenic Escherichia coli. Clin Microbiol Rev. 1998;11:142-201.

5. Jensen BH, Olsen KEP, Struve C, Krogfelt KA, Petersen AM. Epidemiology and clinical manifestations of enteroaggregative Escherichia coli. Clin Microbiol Rev. 2014;27:614-30.

6. Navarro-Garcia F, Elias WP. Autotransporters and virulence of enteroaggregative E. coli. Gut Microbes. 2011;2:13-24.

7. Zhang R, Gu D, Huang Y, Chan EW-C, Chen G-X, Chen S. Comparative genetic characterization of Enteroaggregative Escherichia coli strains recovered from clinical and non-clinical settings. Sci Rep. 2016;6(October 2015):24321.

8. Croxen MA, Law RJ, Scholz R, Keeney KM, Wlodarska M, Finlay BB. Recent Advances in Understanding Enteric Pathogenic Escherichia coli. Clin Microbiol Rev. 2013;26:822-80

9. Nataro JP, Yikang D, Yingkang D, Walker K. AggR, a transcriptional activator of aggregative adherence fimbria I expression in enteroaggregative Escherichia coli. J Bacteriol. 1994;176:4691-9.

10. Navarro-Garcia F, Sears C, Eslava C, Cravioto A, Nataro JP. Cytoskeletal effects induced by Pet, the serine protease enterotoxin of enteroaggregative Escherichia coli. Infect Immun. 1999;67:2184-92.

11. Henderson IR, Czeczulin J, Eslava C, Noriega F, Nataro JP. Characterization of Pic, a secreted protease of Shigella flexneri and enteroaggregative Escherichia coli. Infect Immun. 1999;67:5587-96.

12. Ménard L-P, Dubreuil JD. Enteroaggregative Escherichia coli heat-stable enterotoxin 1 (EAST1): a new toxin with an old twist. Crit Rev Microbiol. 2002;28:43-60.

13. Nataro JP, Deng Y, Cookson S, Cravioto A, Savarino SJ, Guers LD, et al. Heterogeneity of enteroaggregative Escherichia coli virulence demonstrated in volunteers. J Infect Dis. 1995; 171:465-8.

14. Nishi J, Sheikh J, Mizuguchi K, Luisi B, Burland V, Boutin A, et al. The Export of Coat Protein from Enteroaggregative Escherichia coli by a Specific ATP-binding Cassette Transporter System. J Biol Chem. 2003;278:45680-9.

15. Schubert S, Rakin A, Karch H, Carniel E, Heesemann J. Prevalence of the "high-pathogenicity island" of Yersinia species among Escherichia coli strains that are pathogenic to humans. Infect Immun. 1998;66:480-5.

16. Beloin C, Roux A, Ghigo JM. Escherichia coli biofilms. Curr Top Microbiol Immunol. 2008:322:249-89.

17. Mohamed JA, Huang DB, Jiang ZD, DuPont HL, Nataro JP, Belkind-Gerson J, et al. Association of putative enteroaggregative Escherichia coli virulence genes and biofilm production in isolates from travelers to developing countries. J Clin Microbiol. 2007;45:121-6.

18. Müller D, Greune L, Heusipp G, Karch H, Fruth A, Tschäpe H, et al. Identification of unconventional intestinal pathogenic Escherichia coli isolates expressing intermediate virulence factor profiles by using a novel single-step multiplex PCR. Appl Environ Microbiol. 2007;73:3380-90.

19. Raju B, Ballal M. Multidrug resistant enteroaggregative Escherichia coli diarrhoea in rural southern Indian population. Scand J Infect Dis. 2009:41:105-8.

20. Cravioto A, Tello A, Navarro A, Ruiz J, Villafán H, Uribe F, et al. Association of Escherichia coli HEp-2 adherence patterns with type and duration of diarrhoea. Lancet (London, England). 1991;337:262-4.

21. Stepanović S, Vuković D, Hola V, Di Bonaventura G, Djukić S, Cirković I, et al. Quantification of biofilm in microtiter plates: overview of testing conditions and practical recommendations for assessment of biofilm production by staphylococci. APMIS. 2007;115:891-9.

22. CLSI. Methods for Dilution Antimicrobial Susceptibility Tests for Bacteria That Grow Aerobically; Approved Standard - Ninth Edition. vol. 32. 2012
23. Hu J, Torres AG. Enteropathogenic Escherichia coli: Foe or innocent bystander? Clin Microbiol Infect. 2015;21:729-34.

24. Blanco Crivelli X, Bonino MP, Von Wernich Castillo P, Navarro A, Degregorio $\mathrm{O}$, Bentancor A. Detection and Characterization of Enteropathogenic and Shiga Toxin-Producing Escherichia coli Strains in Rattus spp. from Buenos Aires. Front Microbiol. 2018;9(1).

25. Kaur P, Chakraborti A, Asea A. Enteroaggregative Escherichia coli: An Emerging Enteric Food Borne Pathogen. Interdiscip Perspect Infect Dis. 2010;2010:254159.

26. Ifeanyi CI feanyichukwu C, Ikeneche NF lorence, Bassey BE nya, Al-Gallas N, Ben Aissa R, Boudabous A. Diarrheagenic Escherichia coli pathotypes isolated from children with diarrhea in the Federal Capital Territory Abuja, Nigeria. J Infect Dev Ctries. 2015;9:165-74.

27. Patzi-Vargas S, Zaidi MB, Perez-Martinez I, León-Cen M, Michel-Ayala A, Chaussabel D, et al. Diarrheagenic Escherichia coli carrying supplementary virulence genes are an important cause of moderate to severe diarrhoeal disease in Mexico. PLoS Negl Trop Dis. 2015;9:e003510.

28. Orlandi PP, Magalhães GF, Matos NB, Silva T, Penatti M, Nogueira PA, et al. Etiology of diarrheal infections in children of Porto Velho (Rondonia, Western Amazon region, Brazil). Brazilian J Med Biol Res. 2006;39:507-17.

29. Lima IFN, Boisen N, Da Silva Quetz J, Havt A, De Carvalho EB, Soares AM, et al. Prevalence of enteroaggregative Escherichia coli and its virulence-related genes in a case-control study among children from north-eastern Brazil. J Med Microbiol. 2013;62:683-93.

30. Assis FEA, Wolf S, Surek M, De Toni F, Souza EM, Pedrosa FO, et al. Impact of Aeromonas and diarrheagenic Escherichia coli screening in patients with diarrhea in Paraná, southern Brazil. J Infect Dev Ctries. 2014;8:3-8.

31. Breurec S, Vanel N, Bata P, Chartier L, Farra A, Favennec L, et al. Etiology and Epidemiology of Diarrhea in Hospitalized Children from Low Income Country: A Matched Case-Control Study in Central African Republic. PLoS Negl Trop Dis. 2016;10:e004283.

32. Giles-Vernick T, Bainilago L, Fofana M, Bata P, Vray M. Home Care of Children With Diarrhea in Bangui's Therapeutic Landscape (Central African Republic). Qual Health Res. 2016;26:164-75.

33. Dutta S, Guin S, Ghosh S, Pazhani GP, Rajendran K, Bhattacharya MK, et al. Trends in the prevalence of diarrheagenic Escherichia coli among hospitalized diarrheal patients in Kolkata, India. PLoS One. 2013;8:e56068.

34. Moyo SJ, Maselle SY, Matee MI, Langeland N, Mylvaganam H. Identification of diarrheagenic Escherichia coli isolated from infants and children in Dar es Salaam, Tanzania. BMC Infect Dis. 2007;7:92.

35. Ali MMM, Mohamed ZK, Klena JD, Ahmed SF, Moussa TAA, Ghenghesh KS. Molecular Characterization of Diarrheagenic Escherichia coli from Libya. Am J Trop Med Hyg. 2012;86:866-71.

36. Meng CY, Smith BL, Bodhidatta L, Richard S a, Vansith K, Thy B, et al. Etiology of diarrhea in young children and patterns of antibiotic resistance in Cambodia. Pediatr Infect Dis J. 2011;30:331-5.

37. Jimenez Gutierrez E, Pineda V, Calzada JE, Guerrant RL, Lima Neto JB, Pinkerton RC, et al. Enteric Parasites and Enteroaggregative Escherichia coli in Children from Canazas County, Veraguas Province, Panama. Am J Trop Med Hyg. 2014;91:267-72.

38. Tobias J, Kassem E, Rubinstein U, Bialik A, Vutukuru S-R, Navaro A, et al. Involvement of main diarrheagenic Escherichia coli, with emphasis on enteroaggregative E. coli, in severe non-epidemic pediatric diarrhea in a high-income country. BMC Infect Dis. 2015;15:1-7.

39. Czeczulin JR, Whittam TS, Henderson IR, Navarro-Garcia F, Nataro JP. Phylogenetic analysis of enteroaggregative and diffusely adherent Escherichia coli. Infect Immun. 1999;67:2692-9.

40. Elias W, Barros S, Moreira C, Trabulsi L, Gomes T. Enteroaggregative Escherichia coli Strains among Classical Enteropathogenic Escherichia coli O Serogroups. J Cinical Microbiol. 2002;40:3540-2

41. Tokuda K, Nishi J, Imuta N, Fujiyama R, Kamenosono A, Manago K, et al. Characterization of typical and atypical enteroaggregative escherichia coli in Kagoshima, Japan: biofilm formation and acid resistance. Microbiol Immunol 2010;54(6):320-9. 
42. Cennimo D, Abbas A, Huang DB, Chiang T. The prevalence and virulence characteristics of enteroaggregative Escherichia coli at an urgentcare clinic in the USA: A case-control study. J Med Microbiol. 2009;58:403-7.

43. Andrade JAB de, Freymüller E, Fagundes-Neto U. Adherence of enteroaggregative Escherichia coli to the ileal and colonic mucosa: an in vitro study utilizing the scanning electron microscopy. Arq Gastroenterol. 2011;48:199-204.

44. Sarantuya J, Nishi J, Wakimoto N, Erdene S, Nataro JP, Sheikh J, et al. Typical enteroaggregative Escherichia coli is the most prevalent pathotype among E. coli strains causing diarrhea in Mongolian children. J Clin Microbiol. 2004; 42:133-9.

45. Huang DB, Mohamed J a, Nataro JP, DuPont HL, Jiang Z-D, Okhuysen PC. Virulence characteristics and the molecular epidemiology of enteroaggregative Escherichia coli isolates from travellers to developing countries. J Med Microbiol. 2007;56:1386-92.
46. Fujiyama R, Nishi J, Imuta N, Tokuda K, Manago K, Kawano Y. The shf gene of a Shigella flexneri homologue on the virulent plasmid pAA2 of enteroaggregative Escherichia coli 042 is required for firm biofilm formation. Curr Microbiol. 2008;56:474-80.

47. Regua-Mangia AH, Bezerra RMP, Esparis CM, Teixeira LM. Escherichia coli enteroagregativa (EAEC): Filotipagem e resistência a antimicrobianos em um enteropatógeno emergente. Rev Patol Trop. 2009;38:27-34.

48. Ali MM, Ahmed SF, Klena JD, Mohamed ZK, Moussa TA, Ghenghesh KS. Enteroaggregative Escherichia coli in diarrheic children in Egypt: Molecular characterization and antimicrobial susceptibility. J Infect Dev Ctries. 2014;8:589.

49. Kong H, Hong X, Li X. Current perspectivesin pathogenesis and antimicrobial resistance of enteroaggregative Escherichia coli. Microb Pathog. 2015;85:44-9.

50. Høiby N, Bjarnsholt T, Givskov M, Molin S, Ciofu O. Antibiotic resistance of bacterial biofilms. Int J Antimicrob Agents. 2010;35:322-32. 